\title{
The Effect of Team and K3 Cooperation (Health, Safety, Work) on Performance of Employees CV Anugerah Panen Raya
}

\author{
Kiswah Intifadhah Akbar Rizky \\ Narotama University, Surabaya
}

\begin{abstract}
Quality human resources are needed in obtaining the success of the company. This study aims to determine the effect of teamwork and k3 (health, safety, work) on employee performance in Surabaya. The type of research used is quantitative research with a sample of 50 employees of the harvest harvest award who filled the questionnaire as all employees. The data analysis technique used is multiple linear regression analysis. The results showed that teamwork and k3 (health, safety, work) simultaneously had an effect on employee performance in Surabaya. As well as teamwork and k3 (health, safety, work) have a partial effect on employee performance in Surabaya. The higher the teamwork and good health, safety, work, the higher the employee's performance.
\end{abstract}

Keywords: teamwork, k3 (health, safety, work) and employee performance.

\section{BACKGROUND}

In the company that has a phenomenon that is employees who only work and do not have motivation for themselves. Like the thing a worker who works only expects wages without motivation, with this I aim to change the work patterns of thinking that only work without motivation.

Even though employees need to know the importance of cooperation in an organization especially in a company, so that they can achieve effective communication and the level of trust of each employee to help each other, support each other, provide the best quality from each employee, so that they can show results from the business the company becomes more maximal and able to realize these visions and can be a determining factor of the image and quality of the company.

Most workplace accidents in Indonesia are not experienced by workers in the workplace, but occur on the road when the worker leaves or returns to work. "Around 60 percent of workers actually experience work accidents due to traffic accidents, the rest are caused by other causes such as in the workplace. Based on Law Number 1 of 1970 concerning occupational safety, it is stated that workplace accidents do not only occur in the workplace, but also when workers departed or leaving work.

Therefore, our main target is to reduce cases of accidents that can result in death. Every company should be able to meet all the requirements of $\mathrm{K} 3$, for the fulfillment of the elements of safety and health for workers is not only beneficial to improve the welfare of workers, but also become part of the company's needs. "Fulfillment of the K3 will support the company's business activities. For example, it has an impact on increasing worker productivity and also supports the receipt of a product on the market. Meanwhile, from the results of the meeting in Yogyakarta which was joined by 24 Asian and European countries, four recommendations were obtained, namely agreeing to build a productive basis for sharing information on occupational safety and health. In addition, there is also an agreement to strengthen cooperation in tripartite OHS implementation in each country, and regional and international OSH cooperation will be carried out for the research and capacity building of Asem members. Whereas the fourth recommendation is to promote awareness that good implementation of OSH will provide protection and improvement of workers' welfare and have an impact on increasing company productivity. Meanwhile, Ministry of 
Manpower Singapore's Commissioner of Workplace Safety and Health Ho Siong Hin said that through the meeting there was a better understanding among Asem members to identify and enhance cooperation in the implementation of K3. "Next year, the same meeting will be held in Singapore. We hope to continue the results obtained here," he said. Meanwhile, Head of European Union External Relations Unit Kristin Schreiber said, the implementation of K3 is the best solution that can provide benefits to companies and employees.

BTS stands for Base Transceiver Station. BTS is a telecommunications infrastructure that facilitates wireless communication between communication devices and network operators. BTS signal receiver communication devices can be telephone, cellular and wireless networks while the network operators are GSM, CDMA, and TDMA. BTS sends and receives radio signals to mobile devices and converts these signals into digital signals and then sends them to other terminals for message circulation or data and BTS is an element in cellular networks (Cell Network) which plays an important role as signal transmitters and receivers from handphone (MS / Mobile Station). Other names of BTS are Base Station (BS), Radio Base Station (RBS), or node B (eNB). Until now the community has not been able to distinguish between BTS equipment and BTS towers even though the BTS tower is not the BTS itself.

\section{Problem Formulation}

The formulation of the problem in this study are:

1. Is there a significant influence on teamwork on the performance of CV Anugerah Panen Raya Surabaya employees?

2. Is there a significant influence between $\mathrm{OSH}$ on the performance of CV Anugerah Panen Raya Surabaya employees?

3. Is there a significant, simultaneous influence between teamwork and $\mathrm{k} 3$ on the performance of CV Anugerah Panen Raya Surabaya employees?

\section{Benefits of Research}

The results of this study are expected to provide the following:

1. Benefits Theoretical Benefits

The results of this study are expected to contribute specifically in the field of science and also as a consideration of knowledge so that it can be a reference for further research.

\section{Practical Benefits}

The results of this study are expected to be an input for companies to improve and improve employee performance and as a recommendation for management practitioners who run their business.

\section{LITERATURE REVIEW}

\section{Definition of Collaboration Team}

Teamwork is a group whose individual efforts produce higher performance than the number of individual inputs. Teamwork produces positive synergies through coordinated efforts. This has the understanding that the performance achieved by a team is better than the performance of individuals in an organization or a company (Stephen and Timothy 2008).

\section{Team Cooperation Indicators}

Some indicators of team collaboration are

1) Mutual contribution

2) Maximum capacity guidance

3) Responsibility for completing work

\section{Understanding K3 (Health, Safety and Work)}

Occupational Safety and Health Is supervision of people, machines, methods and materials that cover the work environment so that workers do not experience injury (Sedarmayati 2009: 124).

\footnotetext{
Motivation

Indicators Several k3 indicators (health, safety, and work) namely:
} 
1) $\mathrm{k} 3$ rules and procedures are very necessary.

2) The $\mathrm{k} 3$ procedure is easy to implement with a consistent

3) company providing $\mathrm{k} 3$ equipment.

\section{Understanding Performance}

Performance is the work result in the quality and quantity achieved by an employee in carrying out his duties in accordance with responsibility given to him (Anwar Prabu Mangkunegara 2009: 67).

\section{Performance}

Indicators Someindicators are

1) Willing to overtime to complete tasks that are responsible

2) Able to divide the time from each given job

3) The work done accurately and quickly

\section{Research Concept Framework}

Based on background problems, problem formulas, and literature reviews which has been stated, the research concept framework can be described as follows:

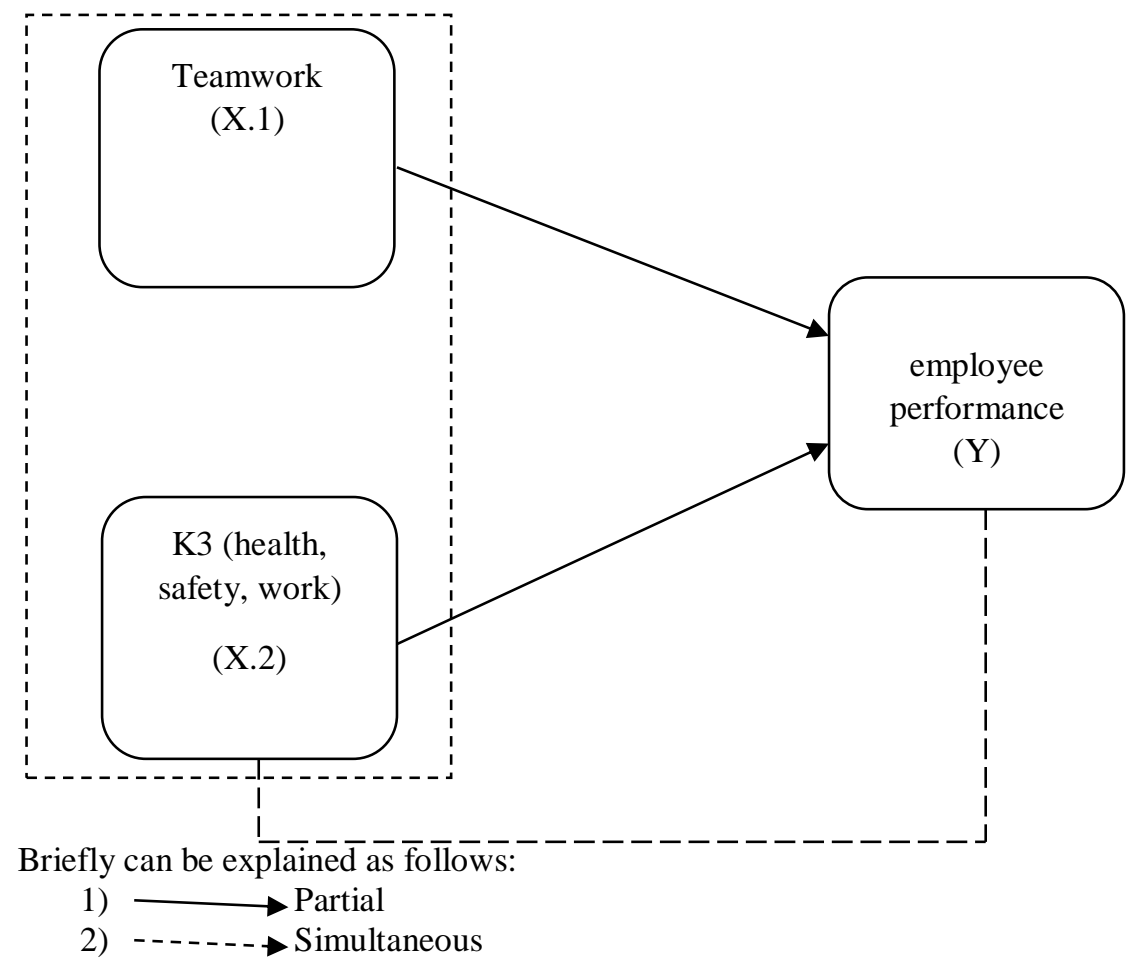

It can be said that team collaboration has a significant effect on employee performance. K3 (health, safety, and work) also greatly affects employee performance.

\section{Hypothesis}

Hypothesis is a conjecture while the truth is still to be tested. Based on the research concept framework above, the researcher can conclude the hypothesis that will be tested in this study are as follows:

1. H1: (X1) teamwork has a significant effect on (Y) employee performance.

2. H2: (X2) K3 (health, safety, work) significantly influences (Y) employee performance.

3. H3: (X1,2) teamwork, and K3 (health, safety, work) simultaneously, have a significant effect on (Y) employee performance. 


\section{RESEARCH METHOD}

\section{Approach}

Quantitative research is a research method that uses the process of data in the form of numbers as a tool to analyze and conduct research studies, especially regarding what has been studied. Kasiram (2008)

\section{Population}

According to Sugiyono (2008: 115), "Population is a region of generalization consisting of objects/subjects that have certain qualities and characteristics. determined by researchers to be studied and then concluded ". The population in this study, all employees in the harvest harvest cv were the objects in this study. The population in this study were all employees of the harvest harvest cv as many as 50 employees of the

\section{Sample}

According to Sugiyono (2008: 116) "the sample is part of the number and characteristics possessed by the population". The sample in this study were 50 employees of the harvest harvest award. Determination of the sample used is a census technique, where all members of the population are used as samples.

\section{Operational Definition Variables}

\section{Team Collaboration (X1)}

Teamwork is a group whose individual efforts produce higher performance than the number of individual inputs. Teamwork produces positive synergies through coordinated efforts. This has the understanding that the performance achieved by a team is better than the performance of individuals in an organization or a company (Stephen and Timothy 2008). In this study the indicators of teamwork are:
a. Mutually contributing
b. to the maximum mobilization of capabilities
c. The responsibility of jointly completing the work of

\section{K3 Variables (Health, Safety and Work) (X2)}

Occupational Safety and Health Is supervision of people, machines, methods and materials which includes the work environment so that workers do not experience injury (Sedarmayati 2009: 124). In this study the indicators of K3 (health, safety, work are:
a. $\mathrm{k} 3$ rules and procedures are indispensable)
b. Easy to implement $\mathrm{k} 3$ procedures The
c. company provides equipment $\mathrm{k} 3$

\section{Employee Performance Variables (Y)}

Performance is the work of quality and quantity achieved by an employee in carry out their duties in accordance with the responsibilities given to him (Anwar Prabu Mangkunegara 2009: 67). In this study indicators of employee performance are:

a. Willing to overtime to complete tasks that are the responsibility

b. Able to divide the time of each given job

c. the work done accurately and rapidly

\section{Engineering Data Analysis}

Data analysis is a method or a way to process a data into information so that the characteristics of the data into an easy to understand and is also beneficial to find solutions to problems, which tertutama is a matter of a study.

The purpose of analyst is data is to describe a data so that it can be understood, and also to draw conclusions or draw conclusions about the characteristics of the population based on the data obtained from the sample, which is usually made with the basis of estimation and hypothesis testing. 


\section{Validity Test}

Means that the measuring instrument used in the measurement can be used to measure what is to be measured (Hasan, 2006: 15). Validity test is intended to test the accuracy of items in the questionnaire, whether the items that exist are able to describe and explain the variables studied. So validity is how far the tool can measure the subject to be measured. According to Iqbal Hasan (2008) "The questionnaire is said to be valid if the questions are able to reveal something that will be regulated by the questionnaire".

\section{Uji Reliability}

Test Reliability is an index indicating the extent to which the measuring instrument is reliable or unreliable. If a measuring device is used twice to measure the same symptoms and the results obtained are relatively consistent, then the measuring instrument is declared reliable (Singarimbun, 2009). Reliability Test is a tool used to measure questionnaires which are indicators of variables. The questionnaire is said to be reliable or reliable, if someone answers the statement consistently from time to time (Ghozali, 2009). A test can be said to have a high level of trust if the test can give the right results. Estimates of high and low reliability can be done through various methods according to the nature and function of the measuring instrument and the level of practicality.

\section{Analysis of Multiple Linear Regression}

This analysis is used to find out how much influence the independent variable is teamwork (X1) and $\mathrm{k} 3$ (X2) on the dependent variable, namely employee performance (Y). The multiple linear regression equation is as follows (Ghozali, 2005):

$$
\begin{array}{ll}
\mathrm{Y} & =\mathrm{a}+\mathrm{b} 1 \mathrm{X} 1+\mathrm{b} 2 \mathrm{X} 2+\mathrm{e} \\
\mathrm{Where} & \\
\mathrm{Y} & =\text { Dependent variable (employee performance) } \\
\mathrm{A} & =\text { Constant } \\
\mathrm{B} 1, \mathrm{~b} 2 & =\text { Regression line coefficient } \\
\mathrm{X} 1, \mathrm{X} 2 & =\text { Independent variable (teamwork and } \mathrm{k} 3) \\
\mathrm{e} & =\text { Standard error }
\end{array}
$$

\section{Classical Assumption Test The classic}

Assumption test is conducted to find out whether the resulting parameters are BLUE (best linear unbiased estimation), meaning that the regression coefficient in the equation does not have significant deviations.

1. Multicollinearity

2. Test Normality

3. Test Heteroscedasticity

\section{Test Hypothesis}

\section{Test Determination $\left(\mathrm{R}^{2}\right)$}

Analysis of multiple correlation coefficients I was used to explain the strength and direction of the relationship between the independent variables and the dependent variable (Sugiyono, 2012). The coefficient of determination (R2) is intended to find out the best level of accuracy in regression analysis, this is indicated by the magnitude of the determination coefficient (R2) between 0 (zero) to 1 (one). If the coefficient of determination of zero means that the independent variable has no effect on the dependent variable at all. If the coefficient of determination gets closer to one, it can be said that the independent variable influences the dependent variable. Because the independent variables in this study are more than 2 , the coefficient of determination used is Adjusted R Square (Imam Ghozali, 2005). From the coefficient of determination (R2), a value can be obtained to measure the magnitude of the contribution of several variables $\mathrm{X}$ to variations in the fluctuations of variable $\mathrm{Y}$ which are usually expressed as a percentage.

\section{T-Statistic Test (Partial)}

$\mathrm{T}$ test (t-test) performs a partial test of the regression coefficient, this test is conducted to determine the significance of the role partially between the independent variables on the dependent variable According to Sugiyono (2014: 250), this study aims to knowing the effect of teamwork (X1), k3 (X2), employee performance (Y) as for the hypothesis in this study are: 
1) Ho: $\beta=0$ : independent variables $(\mathrm{X} 1, \mathrm{X} 2)$, there is no significant effect on the variable (Y)

2) Ha: $\beta \neq 0$ : the independent variable $(\mathrm{X} 1, \mathrm{X} 2)$ has a significant effect on the variable $(\mathrm{Y})$.

3. F Statistic Test (Simultaneous)

According to Imam Ghozali (2013: 98) F statistical test basically shows whether all the independent variables included in the model have a joint effect on the dependent variable. To test these two hypotheses, a statistical test F is used: a) Quick look: if the value of $F$ is greater than 4 , Ho can be rejected at a $5 \%$ confidence level, in other words we accept the alternative hypothesis, which states that all independent variables simultaneously and significantly affect the dependent variable. B) Comparing the value of $\mathrm{F}$ calculated by the value of $\mathrm{F}$ according to the table. If the value of $\mathrm{F}$ count is greater than the value of $\mathrm{F}$ table then $\mathrm{Ho}$ is rejected and $\mathrm{Ha}$ is accepted.

\section{Results of Multiple Linear Regression}

\section{R \& R Determination Test ${ }^{2}$}

The coefficient of multiple determination aims to determine how strong the influence of the relationship of all independent variables together on the dependent variable. The results of the coefficient of determination in this study are as follows:

\section{Determination Test $\left(\mathbf{R} \& \mathbf{R}^{2}\right)$} Model Summary

\begin{tabular}{|l|l|l|r|r|}
\hline Model & $\mathrm{R}$ & \multicolumn{1}{|c|}{$\begin{array}{l}\text { R } \\
\text { Square }\end{array}$} & $\begin{array}{c}\text { Adjusted R } \\
\text { Square }\end{array}$ & $\begin{array}{c}\text { Std. Error of } \\
\text { the Estimate }\end{array}$ \\
\hline $\mathrm{c} 1$ & $.888^{\mathrm{A}}$ & .780 & & .789 \\
$\mathrm{i}$ & & .70894 & & \\
$\mathrm{r}$ & & & & \\
$\mathrm{e}$ & & & & \\
$\mathrm{r}$ & & & & \\
$\mathrm{s}$ & & & & \\
$\mathrm{i}$ & & & & \\
$\mathrm{C}$ & & & & \\
$\mathrm{r}$ & & & & \\
$\mathrm{C}$ & & & & \\
\hline
\end{tabular}

a. Predictors: (Constant), K3, Cooperation_tim

Source of data: SPSS analysis attachment

Based on the results of the data test in the summary model table, the adjusted $\mathrm{R}$ square value was obtained at 0.789 which means that the combination of team collaboration variables (X1) and K3 (X2) affects employee performance (Y) discussed in this study.

\section{Hypothesis Testing}

In testing the hypothesis this research is done by testing both simultaneously (F test) and partially (t test):

\section{F test (Simultaneous)}

TestF test aims to determine the effect of independent variables team collaboration (X1), and $\mathrm{K} 3$ (X2 ) to the dependent variable, namely employee performance (Y). regarding the analysis of the influence simultaneously can be presented in the ANOVA table as follows:

Simultaneous test (Test F) ANOVA $^{b}$

\begin{tabular}{|ll|l|r|r|r|r|}
\hline \multicolumn{2}{|l|}{ model } & \multicolumn{1}{l|}{$\begin{array}{l}\text { Sum of } \\
\text { Squares }\end{array}$} & df & Mean Square & \multicolumn{1}{c|}{ F } & \multicolumn{1}{c|}{ Sig. } \\
\hline 1 & Regression & 88,458 & 2 & 44,229 & 88,000 & $.000^{\mathrm{a}}$ \\
& Residual & 23,622 & 47 & .503 & & \\
\hline
\end{tabular}




\begin{tabular}{|l|r|r|r|l|l|}
\hline Total & 112,080 & 49 & & \\
\hline
\end{tabular}

a. Predictors: (Constant), K3, Cooperation_tim

b. Dependent Variable: Kinerja_karyawan

Source of data: attachment results of analysis of SPSS

From the ANOVA table above obtained the results of hypothesis testing simultaneously with a calculated $F$ value of 88.00 with a significant level of 0.00 . Less than 0.05 , which means that there is a simultaneous significant influence between team collaboration (X1), and $\mathrm{K} 3$ (X2) on employee performance (Y).

\section{T Test (Partial Test)}

Partial test is intended to determine the analysis of the influence of teamwork (X1), and K3 (X2) partially on employee performance $(\mathrm{Y})$.

Partial Test (T Test) Coefficients $^{\mathrm{a}}$

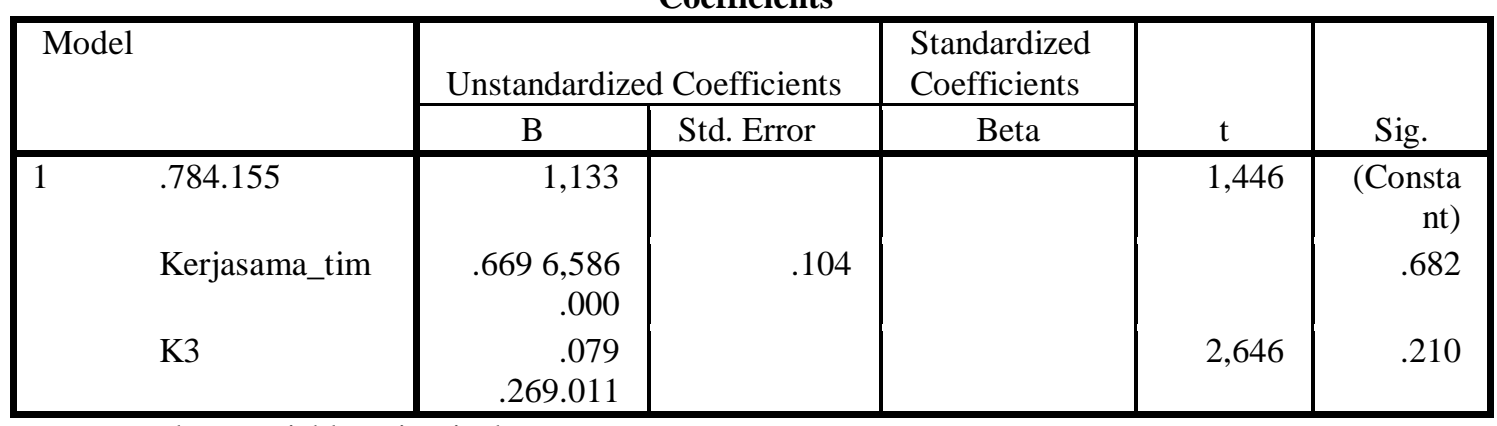

a. Dependent Variable: Kinerja_karyawan

Source: SPSS Analysis Results

From the above coefficients table, the results of the hypothesis test are partially obtained as follows:

1. Effect of variable teamwork (X1) on employee performance (Y), analysis results obtained significant value 0.000 (smaller than 0.05 ) means team collaboration variable (X1) has a significant influence on employee performance $(\mathrm{Y})$.

2. The influence of $\mathrm{K} 3$ (X2) variables on employee performance (Y), the results of the analysis obtained a significant value of 0.011 (smaller than 0.05 ) means that the variable $\mathrm{K} 3(\mathrm{X} 2)$ has a significant influence on employee performance $(\mathrm{Y})$.

\section{CONCLUSIONS}

Based on research on the analysis of the influence of teamwork, and K3 on the performance of employees of the harvest harvest CV in Surabaya. Can be drawn Conclusions from this study are as follows:

1. Teamwork, and K3 simultaneously have a positive effect on the performance of CV. Harvest Harvest Great employees in Surabaya.

2. K3 (health, safety, work) partially influences the performance of CV. Anugerah Panen Raya employees in Surabaya.

3. Team collaboration has a partial effect on the performance of CV. Anugerah Panen Raya employees in Surabaya.

4. From the results of the determination test it is known that teamwork, and K3 affect employee performance by 0.789 . 


\section{REFERENCES}

[1] Kasiram, Moh. 2008. Research Methodology. Malang: UIN-Malang Press.

[2] Stephen P. Robbins and Timothy A. Judge. 2008. Organizational Behavior Issue 12 Book 1. Translation: Diana Angelica, Ria Cahyani and Abdul Rosyid. Jakarta: Salemba Empat.

[3] Sedarmayanti, M.Pd ,. APU. 2009, Human Resources and Work Productivity. Bandung: Advanced Mandar Publishers.

[4] Hasan, Iqbal. 2006. Research Data Analysis with Statistics. Jakarta: Bumi Literacy

[5] M. Iqbal Hasan. (2008). Research Data Analysis with Statistics. PT. Bumi Aksara, Jakarta.

[6] Ghozali, Imam. 2009. "Application of Multivariate Analysis with SPSS Program". Semarang: UNDIP.

[7] Sugiyono. 2012. Qualitative Quantitative Research Methods and R \& D. Bandung: Alfabeta.

[8] Ghozali, Imam. 2013. Application of Multivariate Analysis with IBM SPSS 21 Program PLS Regression Update. Semarang: Diponegoro University Publishing Agency.

[9] Sugiyono. (2014). Educational Research Methods Quantitative, Qualitative and R \& D Approaches. Bandung: Alfabeta.

[10] Ghozali, Imam. 2005. Application of Multivariate Analysis with SPSS. Semarang: UNDIP Publishing Agency. 